\title{
Immobilization of Yeast Cells in Porous Silica Carrier with Sol-Gel Process
}

\author{
Motohiro UO, Kyoko YAMASHITA ${ }^{\dagger}$, Masayasu SUZUKI*, Eiichi TAMIYA*, \\ Isao KARUBE* and Akio MAKISHIMA \\ Department of Materials Science, Faculty of Engineering, The University of Tokyo, 7-3-1, Hongo, Bunkyo-ku, Tokyo \\ *Research Center for Advanced Science and Technology, The University of Tokyo, 4-6-1, Komaba, Meguro-ku, Tokyo \\ ゾル-ゲル法による多孔質シリカ担体への酵母の固定化

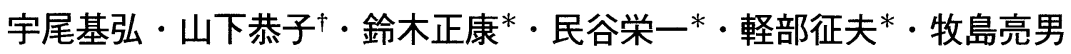 \\ 東京大学工学部材料学科, 113 東京都文京区本郷 7-3-1 \\ *東京大学先端科学技術研究センター, 153 東京都目黒区駒場 4-6-1
}

113

153

[Received November 15, 1991; Accepted January 24, 1992]

\begin{abstract}
The porous silica gels were prepared from tetramethoxysilane (TMOS)-polyethyleneglycol (PEG)- $\mathrm{H}_{2} \mathrm{O}$ methanol solution by the sol-gel process. Microstructure of gel was affected by the composition of starting solutions. The pore diameter of porous gels ranged from $0.1 \mu \mathrm{m}$ to $10 \mu \mathrm{m}$. The pore diameter increased with increasing $\mathrm{H}_{2} \mathrm{O}$ and $\mathrm{H}_{2} \mathrm{SO}_{4}$ contents and with increasing molecular weight of PEG, whilst it decreased with increasing PEG concentration. Yeast cells were immobilized in porous silica gels prepared from TMOSPEG solutions by the sol-gel process. Yeast cells were immobilized as spores. After incubation, yeast spores germed and growth of the yeasts were comfirmed.
\end{abstract}

Key-words : Sol-gel process, Polyethylene glycol, Porous silica carrier, Pore diameter, Yeast, Saccharomyces cerevisiae, Immobilization

\section{Introduction}

The immobilized growing yeast cells are useful for fermentation technology and they were usually prepared with organic carriers such as calcium alginate gels ${ }^{1)}$ or carrageenan. ${ }^{2)}$ In these cases, yeast cells are mixed with the precursor of gels and yeast cells are contained in carriers after gelation. Although such methods are convenient for immobilization, the mechanical strength and chemical durability of organic carriers are inferior to inorganic carriers such as porous glasses and ceramics. The immobilized growing yeast cells were also prepared by the use of porous glasses and porous alumina ceramics, ${ }^{3), 4)}$ In these cases, it is difficult to immobilize a large number of yeast cells as the case with organic carriers.

Thus, the methods to immobilize a large number of yeast cells in inorganic carriers are required. Car-turan et al. ${ }^{5}$ reported the method to immobilize yeast cells in silica gel with sol-gel process and observed invertase activity with these immobilized

\footnotetext{
$\uparrow$ Present address: Department of Urban Engineering, Faculty of Engineering, The University of Tokyo, 7-3-1, Hongo, Bunkyoku, Tokyo 113

現在 : 東京大学工学部都市工学科, 113 東京都文京区本郷 73-1
}

cells. However, yeast cell was not growing and carrier was not porous.

Nakanishi et al. reported the methods to prepare porous silica gel with sol-gel process from silicon alkoxide-organic polymer solution such as tetraethoxysilane (TEOS) -polyacrylic acid (HPAA), 6) TEOSpolyethyleneglycol (PEG), ${ }^{7)}$ tetramethoxysilane (TMOS) - poly (sodium stylenesulfonate) $(\mathrm{NaPSS})^{8)}$ solution. Yazawa et al. ${ }^{9)}$ also reported the pore structures of porous $\mathrm{SiO}_{2}-\mathrm{ZrO}_{2}$ glasses prepared from PEG containing silicon and zirconium alkoxide solution. Considering the pore size of porous gels and toxicity of starting materials for microbes, silicon alkoxide-PEG solution is suitable for the immobilization of microbes with sol-gel method.

In this paper, porous silica gels were prepared by the sol-gel method and their micro structures were studied. And immobilized growing yeast cells in porous silica carriers were also prepared by the solgel method using the TMOS-PEG solution.

\section{Materials and methods}

\subsection{Preparation of porous silica gels}

For preparation of porous silica gels, reagent grade of tetramethoxysilane (TMOS), methanol and polyethyleneglycol (PEG) were used without further purification. The molecular weight of PEG was $2 \times 10^{4}$ (PEG2) and $5 \times 10^{5}$ (PEG5) and the PEG content was estimated by molar ratio of ethyleneglycol (monomer) and TMOS. Compositions of starting solutions are shown in Table 1. For the series $\mathrm{A}$ and $\mathrm{B}$ in Table $1,1 \mathrm{~N} \mathrm{H}_{2} \mathrm{SO}_{4}$ aqueous solution was used instead of $\mathrm{H}_{2} \mathrm{O}$. For the series $\mathrm{C}, \mathrm{H}_{2}$

Table 1. Compositions of starting solutions for gel preparation.

\begin{tabular}{l|cccc|c}
\hline Composition & TMOS & $\begin{array}{l}\mathrm{H}_{2} \mathrm{O} \\
\text { (molar }\end{array}$ & $\begin{array}{c}\text { MeOH } \\
\text { ratio) }\end{array}$ & PEG & Catalyst \\
\hline Series A & 1 & 11 & 2 & $0.5 \sim 1.0$ & $1 \mathrm{~N} \mathrm{H}_{2} \mathrm{SO}_{4}$ aq. \\
Series B & 1 & $5 \sim 15$ & 2 & 0.7 & $1 \mathrm{~N} \mathrm{H}_{2} \mathrm{SO}_{4}$ aq. \\
Series C & 1 & 11 & 2 & 0.7 & $\begin{array}{r}0.005 \mathrm{~N}_{1} \sim 1 \mathrm{~N} \\
\mathrm{H}_{2} \mathrm{SO}_{4} \text { aq. }\end{array}$ \\
\hline
\end{tabular}


$\mathrm{SO}_{4}$ concentration was changed to observe the effect of catalyst concentration on pore diameter of gels.

In the first step, PEG was dissolved in a mixture of $\mathrm{H}_{2} \mathrm{O}$ and methanol and TMOS was added to this solution. After mixing, the solutions were maintained at $40^{\circ} \mathrm{C}$ until gelled. After gelation, the wet gels were soaked in $\mathrm{H}_{2} \mathrm{O}$ at $40^{\circ} \mathrm{C}$ for one week in order to leach out the PEG rich phase. Porous silica gels were prepared by drying at $140^{\circ} \mathrm{C}$ for one day. The distributions of pore diameters smaller than $2 \mu$ m were determined by mercuric porosimetry and those larger than $2 \mu$ m were determined with electron microscopic observation. Differential thermal analysis and thermogravimetric analysis (DTA/TG) were also carried out for porous dry gel.

\subsection{Cultivation and sporulation of yeast}

In this investigation, Saccharomyces cerevisiae (IAM4512) was used. The cells were cultivated in the YEPD medium as shown in Table 2. Yeast cells show sporulation and the spores are durable to organic solvents. Thus, immobilization of yeast cells was carried out with yeast spore in this investigation. Before immobilization, the yeast cells were cultivated in $2 \mathrm{wt} \%$ potassium acetate solution at $30^{\circ} \mathrm{C}$ for $48 \mathrm{~h}$ and sporulation was carried out.

\subsection{Immobilization of yeast}

Before immobilization of yeast cells, pre-hydrolysis of TMOS was carried out in order to diminish the toxicity of TMOS and to avoid the exothermic reaction of hydrolysis of TMOS. The compositions of the solutions for pre-hydrolysis and for immobilization of yeast cells are shown in Table 3. Composition $\mathrm{C}$ in Table 3 was not containing yeast cell and it was prepared as the control. TMOS, $\mathrm{H}_{2} \mathrm{O}$, methanol and PEG were mixed for pre-hydrolysis in the compositions shown in Table 3 and maintained at $20^{\circ} \mathrm{C}$ for 1 day in sealed containers. After pre-hydrolysis, the yeast spore suspension (spore concentration: $5 \times 10^{7}$ spores $/ \mathrm{ml}$ ) were added to each solutions and mixed. After gelation, gels were crashed and soaked in sterilized water for 1 day at room temperature. After

Table 2. Composition of YEPD medium.

\begin{tabular}{lr}
\hline Yeast Extract (DIFCO) & $10 \mathrm{~g}$ \\
Bacto Peptone (DIFCO) & $20 \mathrm{~g}$ \\
Glucose & $20 \mathrm{~g}$ \\
Distilled water & $1000 \mathrm{ml}$ \\
\hline
\end{tabular}

Table 3. Compositions of starting solutions for immobilization of yeast cells (molar ratio).

\begin{tabular}{l|cccc|c}
\hline & \multicolumn{4}{|c|}{ pre-hydrolysis } & addition \\
& TMOS & $\mathrm{H}_{2} \mathrm{O}$ & MeOH & PEG & $\mathrm{H}_{2} \mathrm{O}$ \\
\hline Composition $\mathrm{A}$ & 1 & 2 & 2 & 0.7 & 15 (spore suspension) \\
Composition $\mathrm{B}$ & 1 & 2 & 2 & 0.5 & 9 (spore suspension) \\
& \multicolumn{3}{|c|}{$\left(0.1 \mathrm{NH}_{2} \mathrm{SO}_{4}\right)$} & & \\
Composition $\mathrm{C}$ & 1 & 2 & 2 & 0.7 & 15 (sterilized water) \\
\hline
\end{tabular}

soaking, each gel was immersed in $150 \mathrm{ml}$ of YEPD medium and cultivated at $30^{\circ} \mathrm{C}$ for 10 days. One $\mathrm{ml}$ of each medium was withdrawn for determination of glucose concentration in order to determine the activity of immobilized yeast. All experimental procedures for immobilization and cultivation of yeasts were carried out in sterilized box.

\subsection{Estimation of immobilized yeast activity}

The yeast consumes glucose with oxygen as Eq. (1) and without oxygen as Eq. (2)

$$
\begin{aligned}
& \mathrm{C}_{6} \mathrm{H}_{12} \mathrm{O}_{6}+6 \mathrm{O}_{2}+6 \mathrm{H}_{2} \mathrm{O}=6 \mathrm{CO}_{2}+12 \mathrm{H}_{2} \mathrm{O} \\
& \mathrm{C}_{6} \mathrm{H}_{12} \mathrm{O}_{6}=2 \mathrm{C}_{2} \mathrm{H}_{5} \mathrm{OH}+2 \mathrm{CO}_{2}
\end{aligned}
$$

Thus, the activities of immobilized yeast cells were estimated by glucose consumption under fermentation. Analysis of glucose concentration in medium was carried out with F-kit (Boehringer Mannheim Yamanouchi Co., Ltd.).

\section{Results and discussions}

3.1 Effect of PEG content on pore diameter of gel

Figure 1 shows the microscopic image of the samples from the solutions of series A. For the samples from the solutions of low PEG content (PEG/ TMOS $=0.6$ ), macro pores of several micrometers in diameter are observed. With increasing PEG content, pore size decreased and the morphology of pore of gels became the interconnective. In case of the samples derived from high PEG contents (PEG/ TMOS $=0.9$ ), porous structures were not detected by microscopic observation. Such an effect of PEG contents on pore diameter of gels is shown in Fig. 2. The pore diameter decreased from about $10 \mu \mathrm{m}$ to $0.1 \mu \mathrm{m}$ with increasing PEG content from 0.5 to 1.0 in PEG/TMOS ratio. For the effect of molecular weight of PEG, larger pores were observed in the gels prepared with PEG5. Figure 3 shows the effect of PEG concentration and molecular weight in pore diameter of gels prepared from TEOS-PEG- $\mathrm{H}_{2} \mathrm{O}$-alcohol solution, which is reported by Nakanishi et al. ${ }^{7)}$ The dependences of pore sizes on PEG concentration and molecular weight were almost the same as the present results shown in Fig. 2.

\subsection{Effects of $\mathrm{H}_{2} \mathrm{O}$ and $\mathrm{H}_{2} \mathrm{SO}_{4}$ contents on pore diameter of gel}

Figure 4 shows the effect of $\mathrm{H}_{2} \mathrm{O}$ content on pore diameter of gel prepared from series $\mathrm{B}$ in Table 1. The pore diameter drastically increased with increasing $\mathrm{H}_{2} \mathrm{O}$ content from 10 to 11 (molar ratio against TMOS) and slightly increased in other $\mathrm{H}_{2} \mathrm{O}$ concentration range. The effect of molecular weight of PEG was the same as that shown in Fig. 2. The pore diameters of gels in this result are comparable to that reported by Nakanishi et al. ${ }^{7}$ )

Figure 5 shows the effect of $\mathrm{H}_{2} \mathrm{SO}_{4}$ content on the pore diameter of gel prepared from series $\mathrm{C}$ in Table 1. The pore diameter was found to increase with increasing $\mathrm{H}_{2} \mathrm{SO}_{4}$ content. The gels prepared with PEG5 show porous structure for wide $\mathrm{H}_{2} \mathrm{SO}_{4}$ concen- 


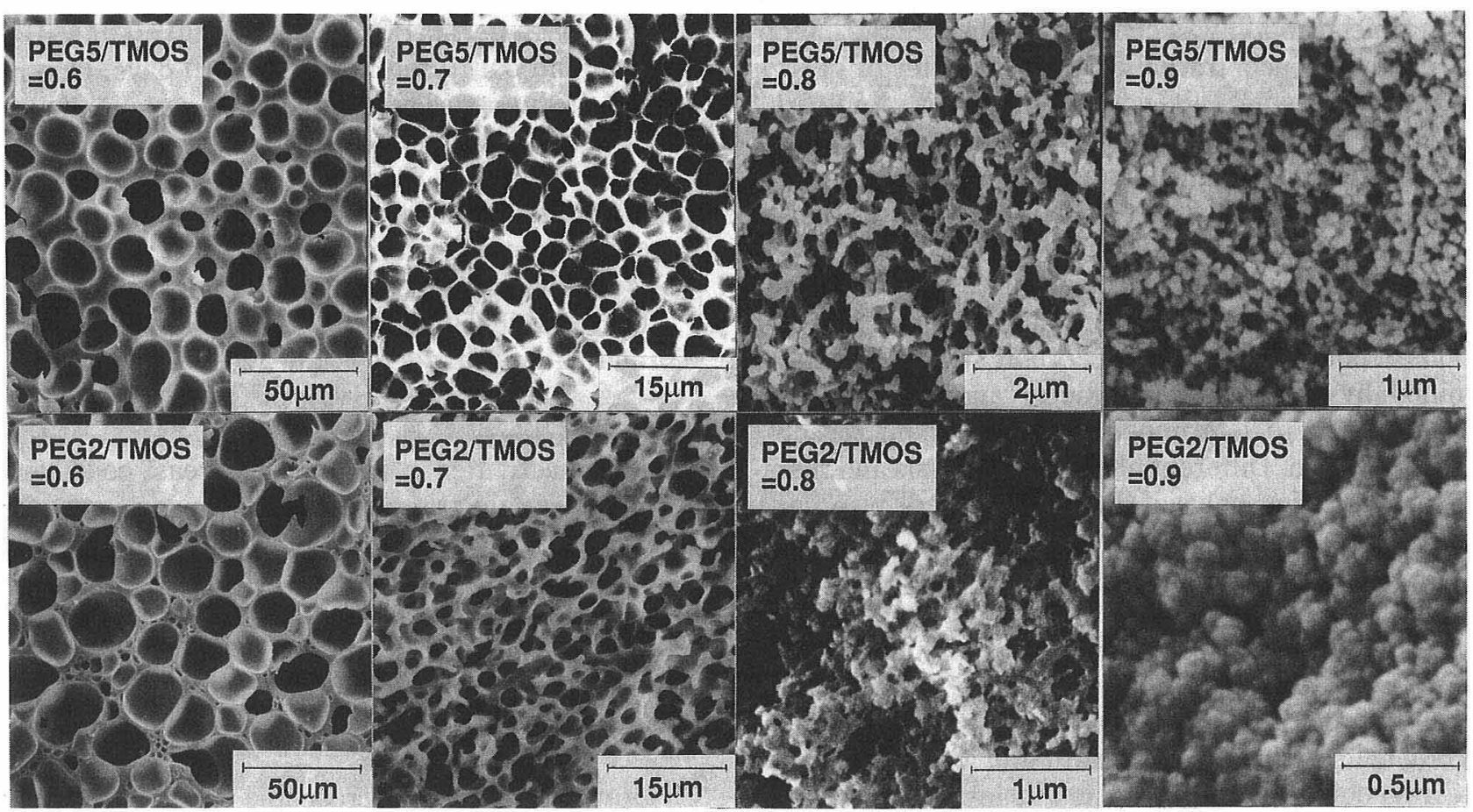

Fig. 1. SEM image of porous silica gels prepared from the solutions of various PEG concentrations and molecular weights.

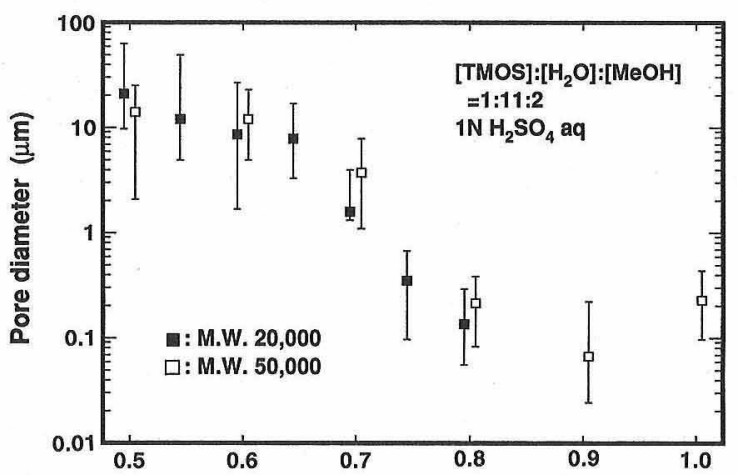

Polyethylene glycol(PEG) concentration (mol/molTMOS)

Fig. 2. Relationship between pore diameter of gels and PEG concentration.

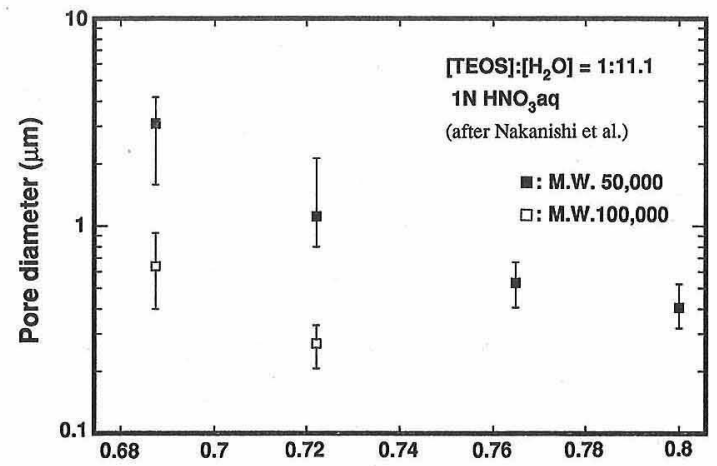

Polyethylene glycol(PEG) concentration (mol/molTEOS)

Fig. 3. Relationship between pore diameter of gels prepared from TEOS-PEG-alcohol- $\mathrm{H}_{2} \mathrm{O}$ system and PEG concentration (after Nakanishi et al. $\left.{ }^{7}\right)$.

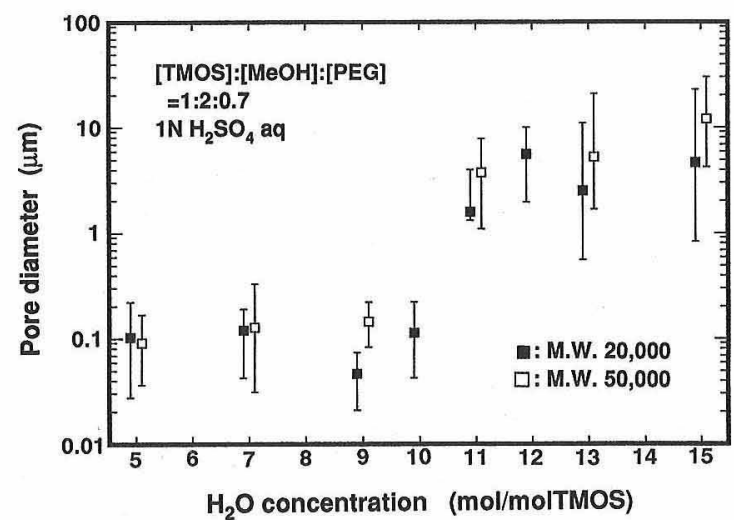

Fig. 4. Relationship between pore diameter of gels and $\mathrm{H}_{2} \mathrm{O}$ concentration.

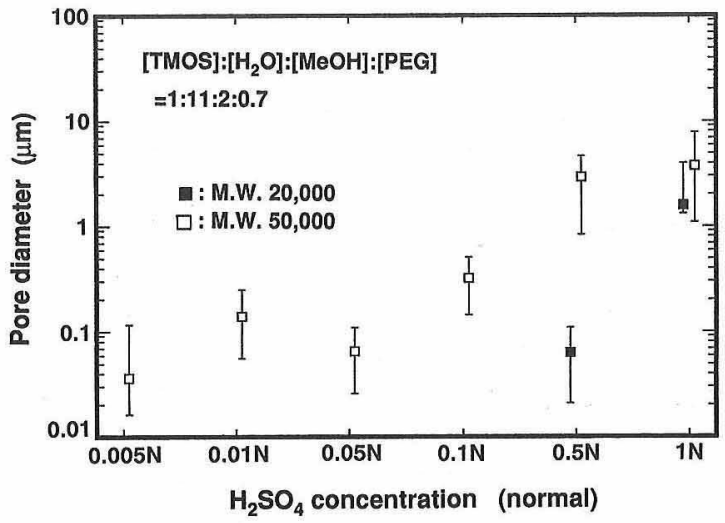

Fig. 5. Relationship between pore diameter of gels and $\mathrm{H}_{2} \mathrm{SO}_{4}$ concentration. 
tration range. However, the gels prepared with PEG2 were transparent and porous structure could not observed.

\subsection{DTA/TG measurement of porous gel}

Figure 6 shows the DTA/TG curves for a porous dry gel. Two peaks accompanied with weight loss are observed at around $60^{\circ}$ and $250^{\circ} \mathrm{C}$. Ota et al. ${ }^{10}$ ) reported the DTA/TG curves of non-porous gels prepared from TEOS-PEG solution. According to their results the endothermic peak at $60^{\circ} \mathrm{C}$ in Fig. 6 is attributed to evaporation of water and methanol and the exothermic peak at $250^{\circ} \mathrm{C}$ is attributed to combustion of residual PEG in porous gel. Thus, it is shown that PEG contained in starting solution was not completely leached with soaking treatment after gelation and some part of PEG remained in silica skeleton.

\subsection{Activity of immobilized yeast cells}

Figure 7 shows glucose concentration change in YEPD media containing immobilized yeast cells during incubation. The glucose concentrations in YEPD media with immobilized yeast continuously decreased, while the glucose concentration in YEPD medium with yeast-free gel was constant. After 10 days of incubation, $1 \mathrm{ml}$ of media were added to YEPD agar plate and growth of yeast cells in each YEPD media was observed. In the plates containing the media incubated with the gels of compositions A and $\mathrm{B}$ in Table 3 , many colonies of yeast cells were

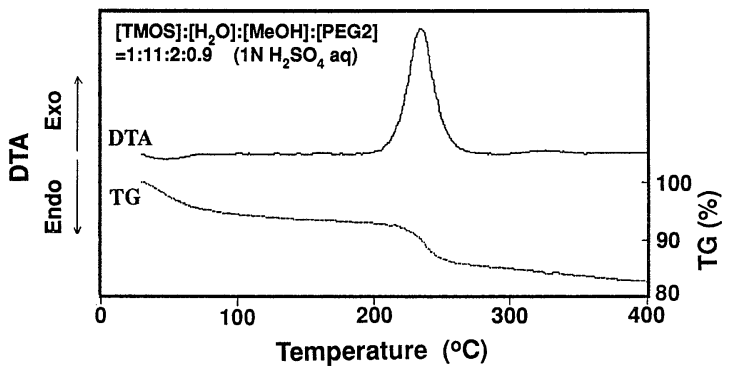

Fig. 6. DTA/TG curves of porous silica gel.

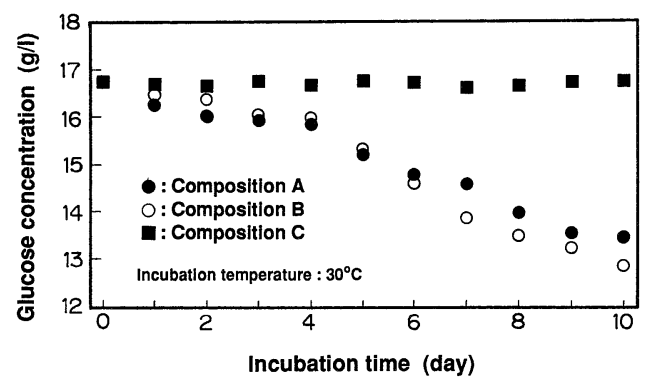

Fig. 7. Glucose concentration change in YEPD media during incubation (Compositions A, B, C are described in Table 3). observed and growth of yeast cells were confirmed. However, no colonies caused by contamination of other microbes were observed in that of composition C.

Thus, the glucose consumption as shown in Fig. 7 was considered to be caused by the germination and growth of yeast, and successful immobilization of yeast cells were confirmed.

\section{Conclusion}

The porous silica gels were prepared from tetramethoxysilane (TMOS)-polyethylene glycol (PEG) $-\mathrm{H}_{2} \mathrm{O}$-methanol solution with sol-gel process. Micro structures of gels were affected by compositions of starting solution. Pore diameters of porous gels were ranging from $0.1 \mu \mathrm{m}$ to $10 \mu \mathrm{m}$. Pore diameter increased with increasing $\mathrm{H}_{2} \mathrm{O}$ and $\mathrm{H}_{2} \mathrm{SO}_{4}$ concentrations and with increasing molecular weight of PEG. Contrarily it decreased with increasing PEG concentration. According to DTA/TG analysis, some PEG still remained in silica skeleton after leaching with water.

Yeast cells were immobilized in porous silica gel prepared from TMOS-PEG solution with sol-gel process. Yeast cells were immobilized as spores. After gelation, immobilized yeasts were incubated in YEPD media and decrease in glucose concentration was observed. The glucose consumption shows germination and growth of yeasts. Thus, yeast cells were successfully immobilized in porous silica carriers with sol-gel process.

Acknowledgement The authors would like to acknowledge Dr. H. Endo of Research Center for Advanced Science and Technology for helpful advice in the preparation of this manuscript. In addition the authors thank to Mr. K. Kotani of National Institute for Research in Inorganic Materials for pore size measurement.

\section{References}

1) M. Kierstan and C. Bucke, Biotechnol. Bioeng., 19, 387-97 (1977).

2) M. Wada, J. Kato and I. Chibata, J. Ferment. Technol., 58, 327-31 (1980).

3) K. K. Bandyopadhyay and T. K. Ghose, Biotechnol. Bioeng., 24, 805-15 (1982).

4) K. Iwasaki and N. Ueno, Seramikkusu Ronbunshi (J. Ceram. Soc. Japan), 98, 1186-90 (1990).

5) G. Carturan, R. Campostrini, S. Dire, V. Scardi and E. De Alteriis, J. Mol. Catal., 57, L13-16 (1989).

6) K. Nakanishi, Y. Sagawa and N. Soga, J. Non-Cryst. Solids, 134, 39-46 (1991).

7) H. Komura, K. Nakanishi and N. Soga, Proceedings of Fall Meeting, The Ceramic Society of Japan (1989) pp. 238-39.

8) K. Nakanishi and N. Soga, J. Am. Ceram. Soc., 74, 2518-30 (1991).

9) T. Yazawa, A. Miyake and H. Tanaka, Seramikkusu Ronbunshi (J. Ceram. Soc. Japan), 99, 1094-97 (1991).

10) R. Ota, A. Watanabe, J. Fukunaga, N. Yoshida, Seramikkusu Ronbunshi (J. Ceram. Soc. Japan), 97, 213-18 (1989). 